\title{
Venture Capital Financing: An Opportunity for Small and Medium Scale Enterprises in Ghana
}

\author{
Francis Boadu \\ Institute of Entrepreneurship \& Enterprise Development, Kumasi Polytechnic \\ P O Box 854, Kumasi, Ghana \\ Tel: 00233244655890 Email: linnacus@yahoo.com \\ Dr. Gabriel Dwomoh (Corresponding author) \\ Institute of Entrepreneurship \& Enterprise Development, Kumasi Polytechnic \\ P O Box 854, Kumasi, Ghana \\ Tel: 00233200991023 Email: gabdwumoo@yahoo.com
}

\author{
Sarpong Appiah \\ Department of Marketing, Takoradi Polytechnic \\ P O Box 256, Takoradi, Ghana
}

Tel: 00233209785832 Email: sarpongappiah@yahoo.co.uk

\begin{abstract}
Elizabeth Dwomo-Fokuo
Institute of Entrepreneurship \& Enterprise Development, Kumasi Polytechnic

P O Box 854, Kumasi, Ghana
\end{abstract}

Tel: 00233208121179 Email: lizzdef@yahoo.co.uk

\begin{abstract}
The paper aims to increase the understanding of venture capital industry in Ghana by examining the role of venture capital financing in aiding small and medium scale enterprises (SMEs) in Ghana. Using the conventional questionnaires administration and interviews, analysis of data collected from the Venture Capital Trust Fund (VCTF) and SMEs supported
\end{abstract}


by venture capitalist (VCs) revealed that venture capital companies contributes in the area of fresh funds (23.8\%), adding value by providing the beneficiaries with skills/training (33.3\%), access to business opportunities (26.2\%) and advisory services (16.7\%). The findings also show that venture capital financing has a positive and statistically significant impact on job creation (33.3\%), revenue for $\mathrm{VC}$ and SMEs (33.3\%), business growth (16.7\%) and expansion $(16.7 \%)$ in a manner consistent with economic expectation.

Keywords: venture capital, small and medium scale enterprise, venture capital trust fund.

\section{Introduction}

Venture capital is a pool of long-term money invested in exchange for equity, in young unlisted fast growing business, with the potential to generate exceptional returns that the venture capitalists (VCs) expect. It is a long-term capital financing for new businesses and rapidly emerging companies (Rose, 2003). Venture Capital firms range from small seed specialist firms to firms with over a billion dollars in invested capital around the world. The venture capitalist is an active investor who has vested interest in guiding, leading and growing the companies they have invested in (Quindlen, 2000). Venture capital is a widely used form of financial intermediation that is particularly well suited to support the creation and growth of young entrepreneurial companies (Hellman and Puri, 2000; Chemmanur, Krishnan, and Nandy, 2011). In the U.S., for example, venture capital has backed many high-tech start-ups that have evolved into major companies that include Digital Equipment Corporation, Apple, Federal Express, Compaq, Sun Microsystems, Intel, Microsoft, Amazon.com, Yahoo, Cisco Systems and Genentech (Gompers and Lerner, 2001; NVCA, 2010). Venture capital has also been credited with stimulating job creation, innovation, and economic growth (Global Insight, 2007 and Kortum and Lerner, 2000). In recent years, venture capital has been discussed increasingly frequently in the literature, as the industry has matured, first in the USA and, more slowly, in the UK. In Ghana, the case is quite different; venture capital financing is a new concept in the country toward SMEs development (just over six years). In Ghana, the Venture Capital Trust Fund Act, 2004 (Act 680) was established as a trust fund to provide financial resources for the development and promotion of Venture Capital financing to SMEs in priority sectors of the economy as shall be specified from time to time, currently the scheme is helping businesses in, information and communication technology, education, pharmaceutical, agro-processing, poultry and financial services. The Venture Capital Trust Fund (VCTF) was resourced with an initial capital fund of US\$ 22.5 million, for investments in the SME sector (VCTF Report, 2006). The VCTF provides credit and equity financing to eligible venture capital financing companies to support small and medium-scale enterprises which qualify for equity, quasi-equity and credit financing; and the provision of monies to support other activities and programmes for the development and promotion of venture capital financing in the country. According to the 2006-2007 Annual Report of the VCTF, in order to achieve the above stated objectives, the fund has partnered with the private sectors to establish various venture capital financing companies (VCFCs) which include Activity Venture Finance Company, Bedrock Venture 


\section{Macrothink}

Journal of Entrepreneurship and Business Innovation

ISSN 2332-8851

2014, Vol. 1, No. 1.

Capital Finance Company, Gold Venture Capital Limited and Fidelity Equity Fund II to assist in the development of SMEs by making available for their use, equity, quasi-equity and credit financing in addition to providing them with technical assistance to boost management expertise and production capabilities. These Venture Capital Finance Companies have in turn invested in a variety of industries nationwide. (www.venturecapitalghana.com, 2013, May 5). Again VCTF may occasionally make direct specific investments to achieve national goals. (www.venturecapitalghana.com, 2013, May 5). The VCTF is under the management of a nine-member Board of Trustees appointed by the President in consultation with the Council of State. (www.venturecapitalghana.com, 2013, May 5). The players of the venture capital market consist of venture capital trust fund, venture capitalist, business angels, and small and medium scale enterprises. The venture capital market is divided into the informal and formal market. Each has its supply and demand. The supply side of the informal market is constituted by the business angels and relatives, while the formal market's supply side is formed by the funds providers and the venture capitalists. The demand-side of both markets is populated by entrepreneurs who seek seed to bridge capital. Venture capital market has tremendous effect on small and medium scale enterprises (Fig.1). Both formal and informal market raises enough capital for business development especially for small and medium scale enterprises for effective running of business activities (Boadu, 2008). The outcome of this phenomenon is job creation, wealth creation, increased revenue through taxes and business growth and expansion. These constitute the social-economic benefits that venture capital market offered.

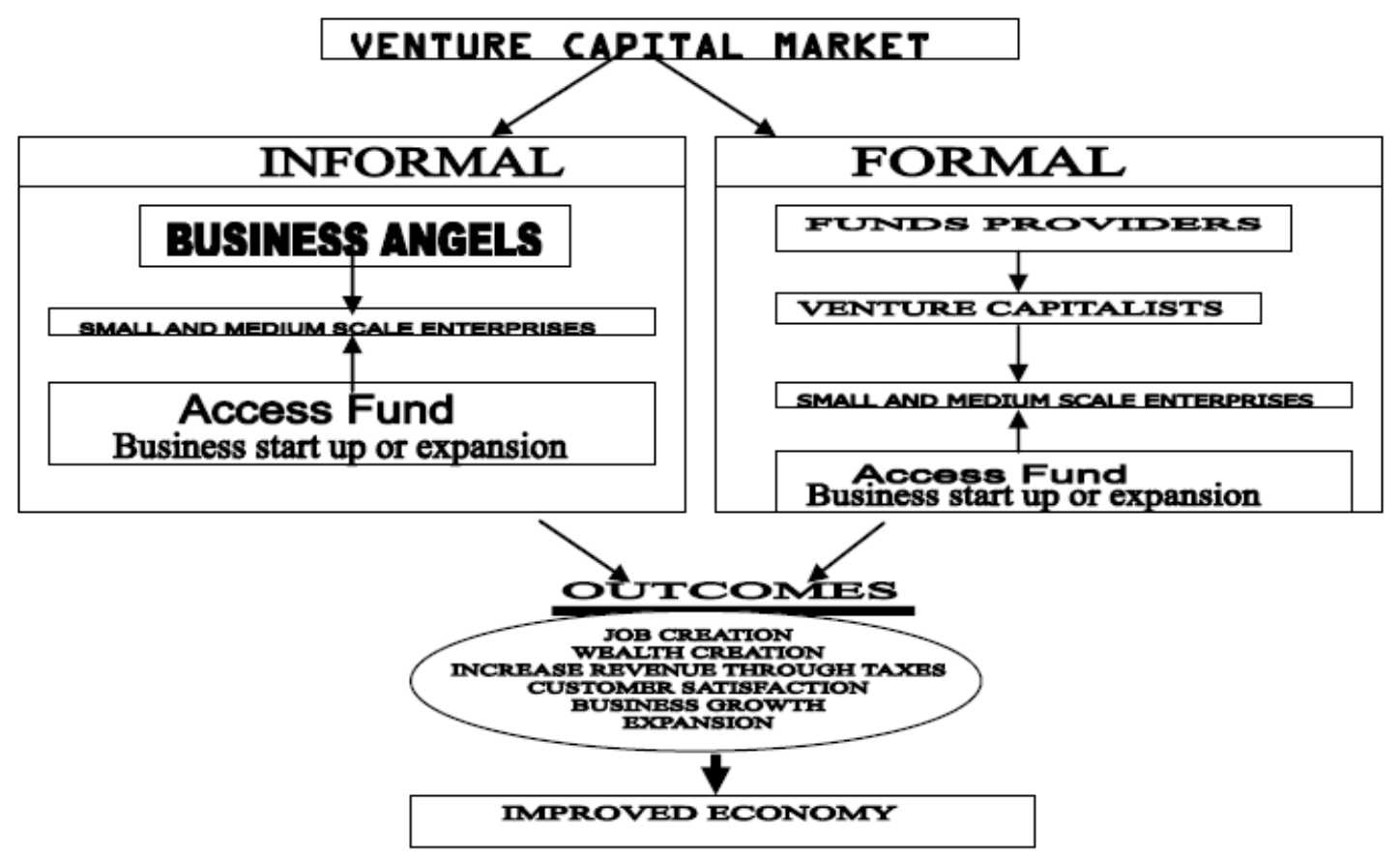

Figure 1: Venture Capital Financing of SMEs in Ghana

Source: Researchers fieldwork, 2013 


\section{Ml Macrothink}

Journal of Entrepreneurship and Business Innovation

ISSN 2332-8851

2014, Vol. 1, No. 1.

Lauriala (2003) suggested that venture capital financing involves the following sequential steps: (1) deal origination, (2) deal screening, (3) deal evaluation, (4) deal structuring, and (5) post investment activities. Margulis and Benjamin (2005) stated that if a venture does not show enough potential or its risk/return ratio is not adequate it might not receive funding. In selecting participating firms, venture capital market based their criterion on business plan, compelling market opportunities, management depth and analysis of applicants' past performance. According to Boadu (2008), a business plan is a critical component of the success of a business and therefore, a sound business plan is the first element of the request for funding and the process of investment usually begins with the assessment of its content. The contents of the business plan in this instance will usually contain the long-term vision of the business, products, market, management structure and financial projections. Also existence of a good market opportunity for entrepreneur's products and services is one criterion that lenders look out for before they fund a venture. To lenders the market risk is more significant than the people risk. Therefore, for entrepreneurs to convince lenders they should be able to demonstrate leadership ability. To venture capitalists, dynamite ideas will go nowhere without dynamite people (Cardis, 2001). The study explores the extent to which venture capital financing is aiding, promoting and maintaining SMEs in Ghana. Our findings could enrich discussions of appropriate policy frameworks that could stimulate entrepreneurship.

\section{Materials and method}

\subsection{Area of Study}

The study is a nation-wide survey concerning the activities of Ghana venture capital trust fund towards small and medium scale enterprises. Ghana has a population of about 24.5 million and an area of 238,537 square kilometers sharing common boundaries with Togo in the east, Burkina Faso in the north and Cote d'Ivoire in the west. The capital city is Accra. It is divided into ten regions, each with a regional capital and distinct cultural identities (Naylor, 2000). Agriculture accounts for about 45 percent of Gross Domestic Product and employs about 60 percent of labour force (Gocking, 2005). Main exports in Ghana are gold, cocoa, timber, bauxite, manganese, diamonds which are called traditional exports, and horticultural products, handicraft. Processed food and manufactured goods called non-traditional exports and its main currency is Cedi/Pesewa.

\subsection{Population}

The target population for the study consisted of all the twenty-one SMEs, sponsored by VCTF across the country as at October, 2012.

\subsection{Sample Size}

The researchers used a total of forty-eight samples made up of chief executive officers and project managers of each of the twenty-one SMEs being sponsored by VCTF and three of the venture capital companies in operation at the time of the study. The first section of the analysis talks about the small and medium scale enterprises which samples chief executive officers and project managers for twenty-one SMEs being sponsored by VCTF which is 
forty-two in total, whiles the second section deals with the chief executive officers and project managers of the three venture capital companies. And in the entire total sample is forty-eight. As at the time of the study, VCTF in collaboration with venture capital companies in Ghana have sponsored twenty-one SMEs, because of small size of the population the researchers decided to use all the SMEs (being sponsored) across the country for the survey.

\subsection{Sampling Procedure}

The researchers employed non probability technique to select sample respondents for inclusion in the sample for the study. The researchers used purposive sampling techniques to select all the elements. The researchers applied this technique because of the expert views of this category of the sample on the subject of the study. Also, this technique was used in this study due to the limited number of SMEs sponsored by VCTF and the method is considered suitable in reaching all the respondents across the country.

\subsection{Research Tools}

Primary data for the study were obtained with the aid of questionnaire administered personally to the respondents. Data collected included sources of finance, training programmes to upgrade SMEs operations, usefulness of venture capital finance, assessment of venture capital companies, investment criteria, the effect of venture capital financing on SMEs, and constraints faced by venture capital companies. Information on general characteristics of SMEs was also obtained. Data gathered were analyzed using descriptive statistics. The survey data were coded, verified and cleaned up, and then entered in a computer and analyzed using the SPSS programme. The findings of the study were presented using appropriate tables and charts to ensure easy interpretation.

\section{Results and discussion}

\subsection{General Characteristics of Small and Medium Scale Enterprises}

This section deals with the analysis of responses from questionnaires administered to the small and medium scale enterprises and management of venture capital companies in Ghana. In all, all the twenty-one portfolio firms (SMEs) being sponsored by venture capital companies were used. Only three of the four venture capital companies responded to the questionnaire (Activity Venture Finance Company, Fidelity Equity Fund II, and Bedrock Venture Capital Finance Company. Gold Venture Capital Limited did not respond to the questionnaire because of restructuring problems at the time. In considering the legal structure of businesses supported by venture capitalists, the result indicate that $38.1 \%$ of small and medium enterprises are partnership, 33.3\% are private limited liability and the remaining $28.6 \%$ are public limited liability. Further examination reveals that the operators of SMEs being sponsored by venture capitalists are in favour of partnership form of business. In the case of the legal structure of venture capital companies in the country today, it is a partnership business between the government of Ghana and some public financial institutions as well as foreign investors. During an interview with a manager of Venture Capital Company concerning the legal structure of SMEs that they have supported, partnership is the one that they have helped most. The manager explained that the partnership form of business is the 
most preferred one as it brings the individuals involved to pool resources together. This will help reduce some of the cost that might have been incurred individually. The age of the businesses varied considerably, the oldest having been established in 2006 and the youngest in 2009. However, more than three-quarters of the firms that had raised direct finance had been founded since 2007. The majority of firms considered themselves to be at the expansion, or sustained growth, stage of their development at the time of the survey.

Table 1. Category of Business Financed by VC

\begin{tabular}{|l|c|c|}
\hline \multicolumn{1}{|c|}{ Category of Business } & Number & Percent of Total \\
\hline Pharmaceutical & 4 & 9.5 \\
Agro-processing & 8 & 19.0 \\
Poultry & 8 & 19.0 \\
Financial Services & 4 & 9.5 \\
Manufacturing & 2 & 4.8 \\
Education & 4 & 9.5 \\
ICT & 10 & 23.9 \\
Waste Management & 2 & 4.8 \\
\hline Total & $\mathbf{4 2}$ & $\mathbf{1 0 0 . 0}$ \\
\hline
\end{tabular}

Source: Field Data, 2013

There are obvious differences in the investment patterns. As can be seen from Table 1, venture capital is more heavily represented in ICT area, agro-processing, and poultry than would be implied by the overall output shares of these industries in the economy as a whole. Venture capital has a slightly smaller share of pharmaceutical and financial services than does the economy as a whole, and a much lower share of manufacturing and waste management. It seems evident that the industries in which venture capitalist concentrate on are those which open up new investment opportunities. For example, the ICT sector may simply have a disproportionately large number of new investment opportunities. It is a growth sector and as such will have high levels of new investment from most financial intermediaries, including venture capitalists and also create employment avenue to a large number of people. An interview with both management of VCTF and venture capital companies buttressed this assertion that ICT has come to stay and for that matter citizenry should take advantage of the super highway as it generates a lot of employment and also allows people to have access to more information.

\subsection{Venture Capital Investment Procedures for Financing SMEs}

This section presents an analysis of findings of the survey which explored the venture capital investment procedures for financing small and medium scale enterprises. Potential entrepreneurs projects go through rigorous processes before they finally get potential investors to come into their aid. Venture capitalists employ a lot of processes to diminish problems of unforeseen circumstances that can cause the entire project. The result in Table 2 
shows that due diligence is ranked overall as an important variable to identify SMEs for financing. Venture capital companies invest in ventures proximately to their outfit in order to spend time on due diligence. In other words, venture capital companies conduct principal audits to know more on legalities of the SMEs, size of the problem that the business was attempting to solve, elegance of the solution, entrepreneurial team, and financial statement among others. This is a time where both parties (VCs and SMEs) get to know each other for 'business marriage'. The respondents attest to the fact that without proper investigation between both parties the marriage can end up on rocks. If an entrepreneur does not succeed with due diligence, venture capitalists would not go any further in the financing process. It is followed by deal origination with a score of 22 . The third and fourth overall ranks are deal screening and structuring respectively. The study affirms the sentiments expresses by Mourdoukoutas and Papadimitrious (2002), they describe due diligence as the first and most critical stage where a series of meetings are held for both parties to get to know one another.

Table 2: Criteria for SMEs Identification

\begin{tabular}{|l|c|c|c|c|c|c|c|}
\hline Rank & 1 & 2 & 3 & 4 & 5 & Score & $\begin{array}{l}\text { Overall } \\
\text { Rank }\end{array}$ \\
& $\begin{array}{c}5 \\
\text { Very } \\
\text { important }\end{array}$ & $\begin{array}{c}4 \\
\text { Moderately } \\
\text { important }\end{array}$ & $\begin{array}{c}3 \\
\text { Fairly } \\
\text { important }\end{array}$ & $\begin{array}{c}2 \\
\text { Important }\end{array}$ & $\begin{array}{c}1 \\
\text { Neutral }\end{array}$ & & \\
\hline Due Diligence & $5(25)$ & $1(4)$ & - & - & - & 29 & $1^{\text {st }}$ \\
\hline $\begin{array}{l}\text { Deal } \\
\text { Origination }\end{array}$ & - & $4(16)$ & $2(6)$ & - & - & 22 & $2^{\text {nd }}$ \\
\hline Deal Screening & $1(5)$ & $1(4)$ & $4(12)$ & - & - & 21 & $3^{\text {rd }}$ \\
\hline Deal Structuring & - & - & - & $6(12)$ & - & 12 & $4^{\text {th }}$ \\
\hline $\begin{array}{l}\text { Venture } \\
\text { Operation }\end{array}$ & & & & & $6(6)$ & 6 & $5^{\text {th }}$ \\
\hline
\end{tabular}

Source: Field Data, 2013

\subsection{What Venture Capital Companies Look for in Business Plan}

Business plan is an entrepreneur guidebook for journey that they have decided to embark on. It helps entrepreneurs to address their short and long term decision making for at least first three years of operations. Venture capitalists go through business plan to determine the viability of the business and also define the rate of return on interest. Of the respondents, $66.6 \%$ look for management team and financial plan in their assessment of business plan of investee companies; $33.4 \%$ look for product and marketing plan in their assessment of business plan. Venture capital companies always investigate a company's past financial history, management team, product and market potential and compare results to businesses in the same industry before any investment is made. This finding suggests that entrepreneurs need to always have in place reputable management team and sound financial background to attract investors into their portfolio businesses. 


\subsection{Effects of Venture Capital Financing on SMEs (Backed by VCC) in Ghana}

This section presents information on the effects of venture capital financing on small and medium scale enterprises backed by venture capital companies in Ghana. Services provided by venture capital companies towards SMEs development in Ghana is shown in Table 3. The highest assistants identified by all respondents were managerial skill/training given to them by venture capital companies. This represents $33.3 \%$ of the total respondents. In addition, $50.0 \%$ of the respondents added that access to finance and business opportunities were given to them by the scheme. This finding suggests that managerial skills training and access to business opportunities have more support to access to advisory service and access to finance of the services given to small and medium scale enterprises by VCs towards their business activities. The interview with the VCTF revealed that they organize frequent training programmes and business opportunities fair to bring people together and share ideas. The study findings tend to support earlier research, notably, Caselli and Gatti (2004) which found that venture capitalists support and strengthen the growth of a company and assist with strategic planning, management recruiting, operations planning or introduction to potential customers and suppliers. However, it is important to point out that the development of small and medium scale enterprises can go a long way to help Ghana achieve its core objectives by creating employment and improving the standard of living of its citizens. Venture capital companies have a tremendous role to play in order to help small and medium scale enterprises achieve their aim towards national development. Therefore, small and medium scale enterprises can achieve this through the assistance they receive from venture capital companies as depicted in Table 3.

Table 3: Services Provided by VCC towards SMEs Development in Ghana

\begin{tabular}{|l|c|c|}
\hline \multicolumn{1}{|c|}{ Category of supports to SMEs } & Number & Percent of Total \\
\hline Managerial Skills/Training & 14 & 33.3 \\
Access to Finance & 10 & 23.8 \\
Access to Advisory Service & 7 & 16.7 \\
Access to Business Opportunities & 11 & 26.2 \\
\hline Total & $\mathbf{4 2}$ & $\mathbf{1 0 0 . 0}$ \\
\hline
\end{tabular}

Source: Field Data, 2013

\subsection{VC Involvement on the Board of the Investee Company}

Hundred percent of the venture capital companies responded positively that they sit on the boards of the investee companies. As opposed to investors in other asset categories who are generally passive shareholders, venture capitalists take an active role in the management of their investees. This is done through participation on the board of an investee, recruiting management to support the investee in fulfilling its strategy and objectives, and sourcing support services that management can take advantage of to increase their capacity to manage the company through stages of growth. This active management allows venture capitalists to protect their investments from bad management which reduces risk in new ventures. An additional advantage of board participation is that it enhances information flow from the 
investee and for that matter reduces problems arising from asymmetric information. This study shows that venture capitalists and management team play a crucial role in board of investee companies. A survey on small and medium scale enterprises revealed that venture capitalists sit on their board to give directions and policies for the smooth running of organizational activities. Also venture capitalists monitor the performance of the management team and provide advice to them. Lerner (2012) studies VC representation on Board of Directors in US and finds evidence of increased VC monitoring during transition periods for their portfolio firms. This phenomenon helps to nurture investee companies through innovations. Hellmann and Puri $(2000,2002)$ find evidence beyond the monitoring role, showing that venture capital backing increases the likelihood of management turnover and influences the product market strategies of the financed firms.

\subsection{Monitoring Level of SMEs Activities in a Year by Venture Capital Companies}

Analysis to determine how venture capital companies monitor the activities of small and medium scale enterprises in a year have been discussed below. It was observed that $66.7 \%$ of the SMEs were of the view that venture capital companies monitor their activities four times within a year, while the remaining $33.3 \%$ of SMEs indicated that their activities are being monitored from a range of five to twenty times a year. This study shows that monitoring is important to venture capital companies. This may be due to the fact that venture capital companies invest huge amounts of money in small and medium scale companies and for that matter do not want to lose it and also allow the management team to misapply its funds. So they always want to monitor the business activities and even instruct their representatives on the board of directors to furnish them with day to day information concerning the business transactions.

\subsection{Economic Impact of VC Financing on SMEs in Ghana}

Talking about the economic impact of venture capital financing on SMEs in Ghana, data gathered through the distribution of questionnaires indicates the following:

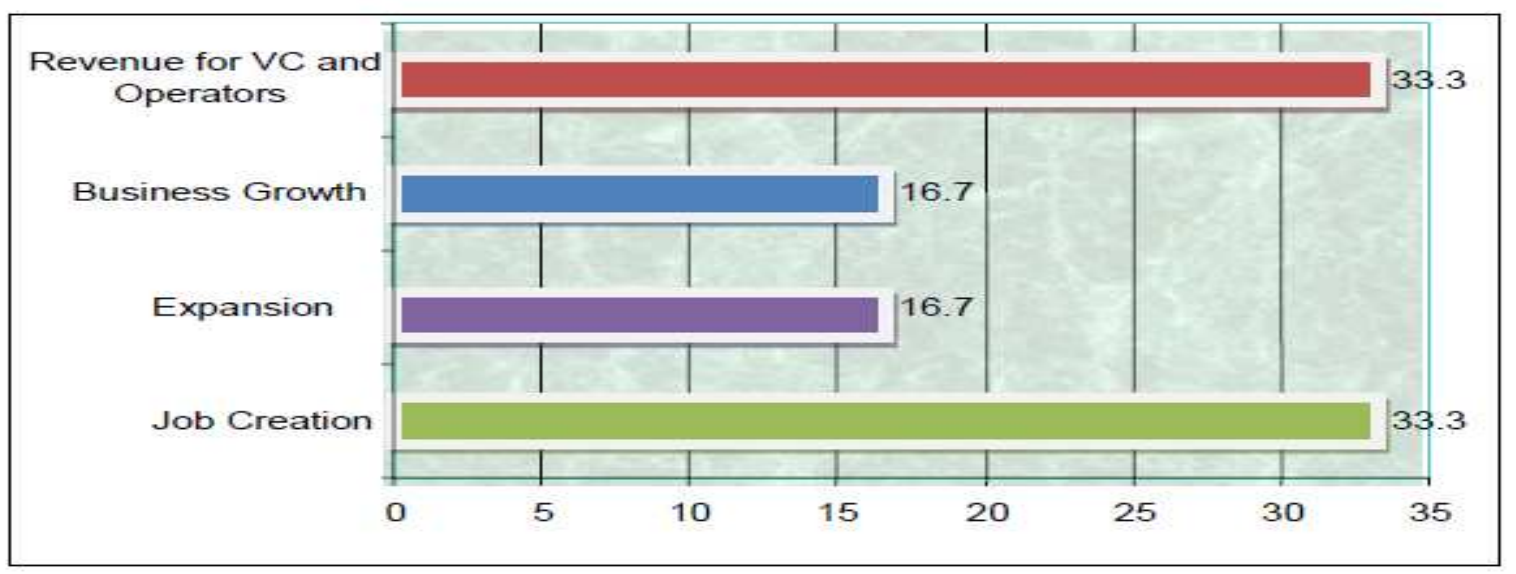

Figure 2: Economic Impact of VC Financing on SMEs in Ghana

Source: Field Data, 2013 


\section{Ml Macrothink}

Journal of Entrepreneurship and Business Innovation

ISSN 2332-8851

2014, Vol. 1, No. 1.

As can be seen from Fig.2, venture capital backed SMEs in Ghana create jobs and revenue for VC and operators in an economy. It also leads SME's to expand and grow their business activities. A number of support services could account for this (Table 3). According to Roger (2003) $78.0 \%$ of the work forces in Japan are employed by small and medium scale enterprises. In Ghana the case is not different, the sector employ over $70.0 \%$ of the available workforce and generating 56.2\% of its private sector turnover (Brown et al., 2003). This suggests that small business owners should be proud that they are a major contributor to the success of the global economy. Venture capital financing helped small and medium scale enterprises to expand and grow their business activities (fig 2). Small and medium scale enterprises achieved this feet through the capital and the consulting services that they received from venture capital firms. This supports the view of Hellman and Puri 2002; McMenamin (1999), which suggested that venture capital, assists in the development of new products or services due to the financial and contributory support that venture capitalists give to thriving and new businesses (Table 3). It is easy to understand why policy-makers are so fond of venture capital. Both academic and practitioner-oriented research clearly demonstrate that venture capital investing add value. A recent study by the National Venture Capital Association (www.nvca.com 2010, March 10) documented the scale and economic impact of 30 years of VC investment in the United States. Over the three decades 1970-2000, American venture capitalists invested no less than $\$ 273.3$ billion into companies in all 50 states. These firms now employ 7.6 million people and generate over $\$ 1.3$ trillion in annual sales revenue, representing $5.9 \%$ and $13.1 \%$ of the U.S national totals respectively. The NVCA study found that on the average every, $\$ 36,000$ in VC investment creates one new job. This means that if necessary support (both financial and training) is given to venture capital companies by the state to guide, lead and grow SMEs, it will generate employment to lessen the acute unemployment situation facing Ghana. In addition, it will also generate revenue for the state in terms of taxes.

\subsection{VC Financing as a Solution to SME Financial Predicaments}

In ascertaining whether venture capital financing serves as a solution to SMEs financial predicaments, questionnaires distributed to the respondents gave the following responses:

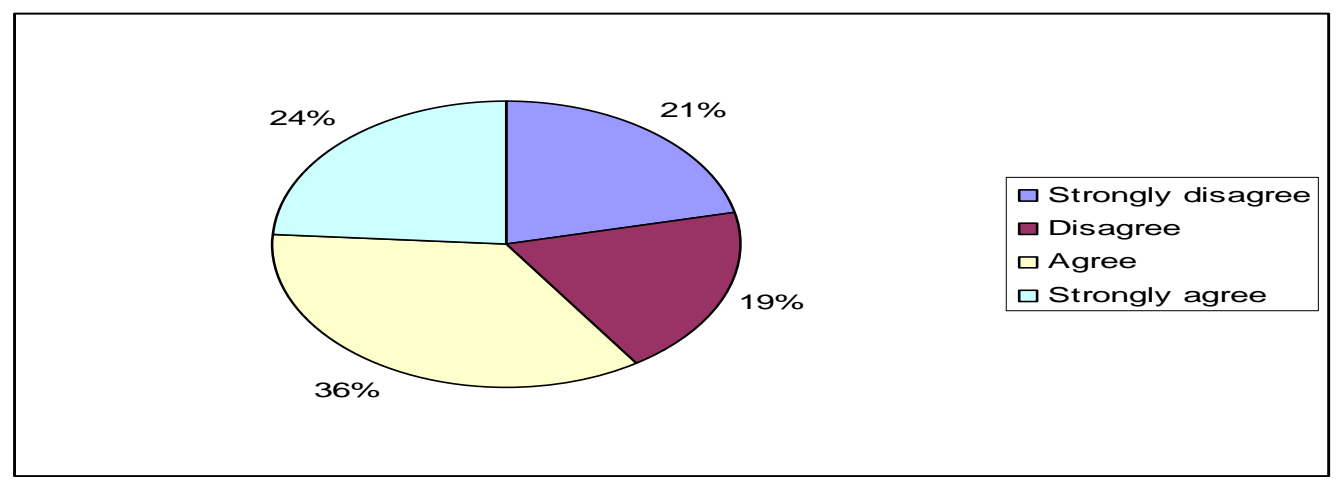

Figure 3: VC Financing as a Solution to SMEs Financial Predicaments.

Source: Field Data, 2013 


\section{Ml Macrothink}

Journal of Entrepreneurship and Business Innovation

ISSN 2332-8851

2014, Vol. 1, No. 1.

Figure 3 display the view of SMEs being sponsored by venture capital companies. This survey examined the reactions of SMEs whether the establishment of venture capital trust fund is a solution to SMEs financial predicament. Sixty percent of the SMEs agree to that assertion, while $40.0 \%$ gave a contrary answer. In Ghana, as well as other African countries access to finance is consistently cited as a principal constraint on the development of small and medium scale enterprises. But the question is doing the small and medium scale enterprises know the entire avenue to get funds from for their projects and the benefits attached to the package? Small and medium scale enterprises should see venture capital firms as avenue where they can get capital as well as free consultancy services. The respondents were of the view that venture capital has come as a solution to most small and medium scale enterprises across the continent and Ghana is not left out (fig 3). Venture capital firms provide new promising companies with a lot of assistance including money and other additional support to SMEs business activities to grow and expand (fig 2). The study shows that VC is a viable solution to some of the financial challenges of SMEs. The literature review indicates that VC has helped a lot of companies like Dell, Compaq, Microsoft, etc. financially to be where they are today as leading companies across the globe (N VCA, 2010).

\subsection{Perception on Venture Capital Financing by SMEs}

Figure 4 examines the perception of small and medium scale enterprises on venture capital financing.

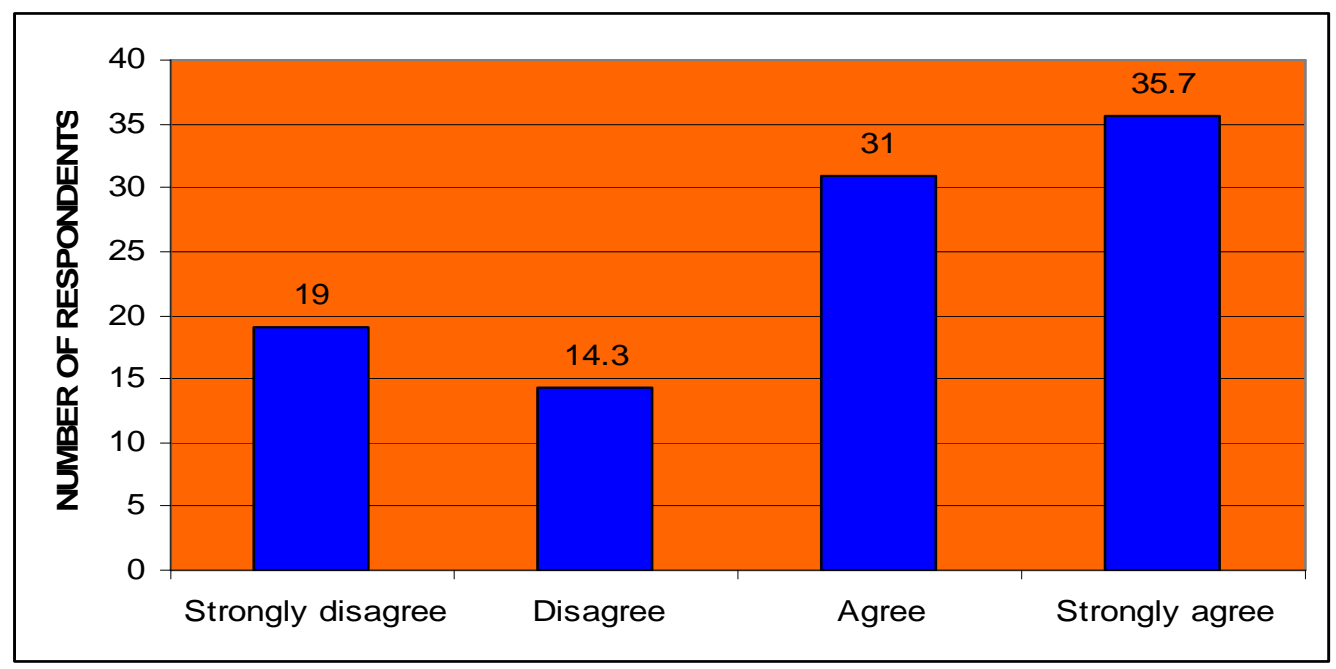

Figure 4: VC Interventions and Business Development

Source: Field Data, 2013

The figure shows scores of venture capital interventions and business development in Ghana. Twenty-eight small and medium scale enterprises representing $66.7 \%$ believe that venture capital financing assists business development and growth in the country and they are prepared to access this source of finance as and when it becomes necessary, while the remaining 14, representing 33.3\% appear undecided. This seems to support the European Private Equity Association view that venture capital financing significantly helped companies to develop. A study by the European Private Equity and Venture Capital Association 
(EVCA) (www.evca.com, 2010 March 10), entitled "The Economic Impact of Venture Capital in Europe," found that VC-backed European companies generated significantly higher growth rates in sales, exports and job creation during the 1990-1995 period than otherwise comparable non-VC-backed companies did. In Ghana, the situation is not quite different, as at December 2007, the VCTF financial report indicated that a total of 3500 farmers had benefited directly from the Trust Fund's facility with an additional 53,698 people affected indirectly. Direct net income to the farmers grew from Gh $\varnothing 102,000$ in the previous year to $\mathrm{Gh} \varnothing$ 371,250 for the 2007 farming season, representing a $264 \%$ increase.

\subsection{General impression of SMEs towards Venture Capital Companies and Venture Capital Companies towards SMEs}

During the study it was revealed that SMEs have certain impression towards VCC and also VCC has a different opinion about SMEs. Below is the discussion of perceptions of SMEs towards VCC. The study shows that majority of SMEs perceived the operation of the venture capital financing as difficult to understand and frustrating. An interview with a manager from venture capital trust fund asserts that most SMEs come to their outfit without proper business plan and financial statement, and it hinders the investment process. In addition, most of the SMEs require financial assistance from venture capital companies in the form of debt (loan) and not equity (sharing of ownership). In other words their willingness to partner venture capital companies is not that certain because they are not prepared to dilute their ownership. Approximately $23.0 \%$ of SMEs claimed that it is not easy to access venture capital (in regard to application process, business plan, due diligence process among others) as compared to traditional financing. This is affirmed by the three venture capital companies surveyed. They explained that venture capital is a risk capital, so they need to conduct proper evaluation and due diligence before settling on one venture. Again 20.7\% of SMEs see venture capital financing as intermediary towards their business operations. They claimed that venture companies have helped them in the area of managerial skills training, advisory services, and recruitment of employees. Small and medium scale enterprises identified inexperienced team and regulators, lack of progressive policies for ICT and infrastructure risk as major constraints facing venture capital financing in Ghana. Approximately 33.0\% of venture capital companies surveyed confirmed that they lack progressive policies for ICT.

\section{Conclusion}

The impact of financing of small and medium scale enterprises in Ghana has raised questions of great concern to stakeholders, particularly business operators who have suffered in terms of getting access to financial assistances. While a number of studies have been commissioned by government and other agencies to investigate why small and medium scale enterprises continue to cry for help in terms of finance, independent studies on impact of venture capital financing of SMEs have not been conducted. This paper therefore, considered the effect of venture capital financing of SMEs using primary data obtained from twenty-one SMEs drawn purposively from ten (10) regions of Ghana. The study revealed that ICT is the most financed sector by VCC and VCTF, this may be a growing nature of it, and therefore can attract high levels of new investment. The result shows that venture capitalist and management team play 
a crucial role in board of investee companies to give directions and policies for the smooth running of organizational activities. It was evident that due diligence play a crucial step in venture capital investment process, and it is first and most critical stage where a series of meetings are held for both parties to get to know one another. Also, the study revealed that venture capital financing has a positive and statistically significant impact on job creation (33.3\%), revenue for VC and SMEs (33.3\%), business growth (16.7\%) and expansion (16.7\%) in a manner consistent with economic expectation. Finally, it was clear that venture capital companies contributes in the area of fresh funds (23.8\%), adding value by providing the beneficiaries with skills/training $(33.3 \%)$, access to business opportunities $(26.2 \%)$ and advisory services $(16.7 \%)$.

\section{Recommendations}

In the light of the findings and conclusion, in order to provide continual support to SMEs and entrepreneurial ventures of the Ghanaian environment, the government must play a leading role by enacting and enforcing stringent laws to increase venture capital awareness, knowledge, expertise, role among entrepreneurs in Ghana, as well as guarantee the SMEs a better financing package. Also, deliberate intervention policies between VCTF and venture capital companies must be implemented speedily to embark on massive educational and information programme on venture capital support activities in order to disseminate needed information to as many people as possible. Moreover, it is recommended that VCTF and venture capital companies should embark on effective fundraising activities within the country and abroad to raise funds to help more small and medium scale enterprises.

\section{References}

Boadu, F. (2008). Venture Capital Financing of Small and Medium Scale Enterprises in Ghana. MPhil Thesis, Kwame Nkrumah University of Science and Technology, (unpublished).

Brown, J.D.,Earle,J.S., and Lup, D. (2003). What Makes Small Firms Grow? Finance, Human Capital, Technical Assistance, and the Business Environment in Romania. Upjohn Institute, Kalamazoo, MI, No. Staff Working Paper.

Cardis, J. (2001). Venture Capital. The Definitive Guide for Entrepreneur, Investors and Practitioners, Wiley, New York.

Caselli, S. \& Gatti, S. (2004). Venture Capital: A Euro-System Approach. Berlin; Springer.

Chemmanur,T.J., Krishnan, K., Nandy, D. (2011). How Does Venture Capital Financing Improve Efficiency in Private Firms? A Look Beneath the Surface. Review of Financial Studies 24:4037-90

Dow Jones (2009). Cisco Uses Venture Capital to Push into South Korea. 09/03/2009 Dow Jones Venture Wire 
EVCA (2005). Employment Contribution of Private Equity and Venture Capital in Europe, Evca, Zaventem.

Global Insight (2007). Venture Impact: The Economic Importance of Venture Capital Backed Companies. Fourth Edition, National Venture Capital Association.

Gockings, S.R. (2005). The History of Ghana, $2^{\text {nd }}$ Edition. Westport: Greenwood Press.

Gompers, P. and Lerner, J. (2001). The Venture Capital Revolution. The Journal of Economic Perspectives, 15, 2, pp 145-168

Hellman, T., and Puri, M. (2000). The Interaction Between Product Market and Financing Strategy: The Role of Venture Capital, Review of Financial Studies 13 (4) (2000).

Hellman, T., and Puri, M. (2002). Venture Capital and the Professionalisation of Start-Up Firms; Empirical evidence, Journal of finance. 57, 169-197.

Kortum, S. and Lerner, J. (2000). Assessing the Contribution of Venture Capital to Innovation, The Rand Journal of Economics 31 (4) (2000).

Lauriala, J.(2003). Introduction to Venture Capital Business Model. Finland: Replicon Corporate Finance.

Lerner, J. (2009). Venture Capital and Private Equity. A Casebook: Wiley, New York.

Lerner, J. (2011). The Future of Private Equity. European Financial Management, 17(3), 423-435

Lerner, J.,Sorensen, M., and Stromberg, P. (2011). Private Equity and Long-Run Investment: The Case of Innovation. Journal of Finance, 66(2), 445-477.

Lerner, J., Leamon, A., and Hardymon, F. (2012). Venture Capital, Private Equity and the Financing of Entrepreneurship. A Casebook: $5^{\text {th }}$ Edition Wiley, New York.

Lili W.(2003). Seminar on Venture Capital and Start-up Companies. Asia-Pacific Economic Cooperation, December 10-11, 2003 Beijing, China.

Margulis,J.B.,and Benjamin, G.A. (2005). Angel Financing: How to Raise Early-Stage Private Equity Financing Hoboken: Wiley and Sons. Inc

McMenamin, J. (1999). Financial management an introduction. London:Routledge. 


\section{Macrothink \\ Journal of Entrepreneurship and Business Innovation \\ ISSN 2332-8851 2014, Vol. 1, No. 1.}

Mourdoukoutas, P. and Papadimitriou, S. (2002). Nurturing Entrepreneurship: Institutions and Policies. Westport: Quorum Books

Naylor, R. (2000). Ghana. An Oxfam Country Profile. Oxfam Great Britain.

NVCA, (2008). National Venture Capital Association. Year book. Arlington.

NVCA, (2010). Emerging Best Practices for Building the Next Generation of Venture-Backed Leadership. Nvca, Arlington

Quindlen, R. (2000). Inside the high-stakes world of start-up financing. New York: Time Warner.

Republic of Ghana (2003). The Ghana ICT for Accelerated Development (ICT4AD) Policy, 95pp.

Robinson, R.J and Osnabrugge, M.V. (2000). Angel Investing: Matching Start-Up Funds with Start-Up Companies (San Francisco: Jossey - Bass).

Rogers, R. (2003). The Entrepreneur's Guide to Finance and Business: Wealth Creation Techniques for Growing a Business. New York: McGraw Hill

Rose, S. P. (2003). Money and capital Markets $8^{\text {th }}$ Edition. New York: McGraw hill

Silver, D.A (1985). Venture Capital: The Complete Guide for Investors, Wiley, New York, NY.

Timmons, J.A., and Bygrave, W.D. (2009). Venture Capital's Role in Financing Innovation for Economic Growth. SSRN Working Paper Series.

VCTF Act, 2004 (Act 680)

VCTF Report 2006

Www.venturecapitalghana.com (5 May 2010)

Www.evca.com $\left(10^{\text {th }}\right.$ March 2010) 